\title{
Efek Investasi Terhadap Pertumbuhan Ekonomi di Pulau Jawa dan Pulau Sulawesi
}

\author{
Muh Jamil* \\ Ekonomi Pembangunan Universitas Negeri Makassar \\ Email:muhjamil@unm.ac.id \\ *Corresponding Author
}

\begin{abstract}
Abstrack. This research aimed to analyze Efect Of Investment to economic growth in Java island and Sulawesi island in 2006-2013. The research used the secondary data, time series and cross section of the eight provinces, namely Jakarta, West Java, Central Java, East Java, North Sulawesi, Central Sulawesi, South Sulawesi and Southeast Sulawesi. The data used comprised the investment index and economic growth index. The data were then Analyzed using Structural Equation Model (SEM) processed using Amos and SPSS econometric software. The results showed that the effect of investment on positive economic growth was significant on Java and positively insignificant on Sulawesi Island. That means that each increase in investment by one percent increases economic growth by 0.479 percent on Java and on Sulawesi Island investment has no effect on economic growth. The investment spread in Java is more stable from year to year and from region to region. Different things on the island of Sulawesi, investment is not stable, sometimes very high and sometimes also very low in other years.
\end{abstract}

Keywords: Investment; Economic Growth

\begin{abstract}
Abstrak. Penelitian ini bertujuan untuk menganalisis efek investasi terhadap pertumbuhan ekonomi di Pulau Jawa dan Pulau Sulawesi periode tahun 2006-2013 menggunakan data sekunder berupa data time series dan cross section dari delapan propinsi yaitu DKI Jakarta, Jawa Barat, Jawa Tengah, Jawa Timur, Sulawesi Utara, Sulawesi Tengah, Sulawesi Selatan dan Sulawesi Tenggara. Menggunakan data yaitu: investasi dan pertumbuhan ekonomi. Dianalisis dengan menggunakan Struktural Equation Model (SEM) diolah dengan menggunakan software ekonometrik Amos dan SPSS. Hasil penelitian menunjukkan bahwa efek investasi terhadap pertumbuhan ekonomi positif signifikan pada di Pulau Jawa dan positif tidak signifikan di Pulau Sulawesi. Hal itu berarti bahwa setiap peningkatan investasi sebesar satu persen meningkatkan pertumbuhan ekonomi sebesar 0.479 persen di Pulau Jawa dan di Pulau Sulawesi investasi tidak berpengaruh terhadap pertumbuhan ekonomi. Sebaran investasi di Pulau Jawa lebih stabil baik dari tahun ketahun maupun dari wilayah ke wilayah lainnya. Hal yang berbeda di Pulau Sulawesi, Investasi tidak stabil, kadang sangat tinggi dan kadang pula sangat rendah pada tahun yang lain.
\end{abstract}

Kata Kunci: Investasi; Pertumbuhan Ekonomi

\section{PENDAHULUAN}

Penelitian ini sangat penting untuk menguji kebenaran teori para ekonom, sekaligus untuk menguji apakah teori teori tersebut relevan untuk Negara Indonesia khususnya wilayah yang menjadi objek penelitian mengingat masing masing punya karateristik yang berbeda.

Menurut para ekonom yaitu Harrod \& Domar dalam Perkin (2001), Todaro (2000), Robert Solow dalam Perkin (2001) dan Romer (1989), Investasi merupakan faktor sangat penting dalam pertumbuhan ekonomi. Tabungan dan investasi merupakan kekuatan sentral dibalik pertumbuhan ekonomi. Pertumbuhan ekonomi ditentukan secara bersama-sama oleh rasio tabungan nasional dan rasio modal output. Salah satu indikator keberhasilan pelaksanaan pembangunan yang dapat dijadikan tolak ukur secara makro adalah pertumbuhan ekonomi (Bunaya, Musa, \& Rahmatullah, 2019).

Akan tetapi, yang terjadi di Indonesia dalam beberapa tahun terakhir terjadi peningkatan investasi namun pertumbuhan ekonomi tidak mengikutinya. Investasi meningkat seharusnya pertumbuhan ekonomi juga demikian, namun dalam fakta menunjukkan pertumbuhan ekonomi justru cenderung menurun. Perekonomian nasional diurus dan dikelola dalam bentuk apapun, pada akhirnya harus berpangkal pada usaha bersama dan berujung pada kesejahteraan sosial (societal 
welfare), yaitu pada suatu kemakmuran bersama seluruh masyarakat bukan kemakmuran orang seorang (Inanna \& Rahmatullah, 2018).

Pertumbuhan investasi di Pulau Jawa yang terdiri dari empat propinsi yaitu DKI Jakarta, Jawa Barat, Jawa Tengah dan Jawa Timur mengalami peningkatan secara kuantitas dari tahun ketahun, puncak peningkatan pada tahun 2011 sampai 2013 tetapi dampak terhadap pertumbuhan ekonomi justru negatif. Pertumbuhan ekonomi menurun dari 6.2 persen tahun 2011 menjadi 6.07 persen tahun 2012, bahkan lebih parah lagi menurun menjadi 5.86 persen pada tahun 2013. Hal ini bertentangan dengan teori investasi yang dikemukakan oleh Harrod \& Domar dalam Perkin (2001), Solow dalam Perkin (2001) dan Romer (1989), bahwa setiap peningkatan modal dalam bentuk investasi akan meningkatkan output dan pertumbuhan ekonomi.

Jika dibandingkan dengan fenomena yang terjadi di Sulawesi yang terdiri dari empat propinsi pula yaitu Sulawesi Utara, Sulawesi Tengah, Sulawesi Selatan dan Sulawesi Tenggara. Pada kasus Sulawesi peningkatan investasi cenderung positif. Investasi meningkat menyebabkan pertumbuhan ekonomi meningkat sebaliknya investasi menurun menyebabkan pertumbuhan ekonomi menurun. Lebih lengkapnya bisa dilihat pada grafik 1 dan 2 berikut:

Grafik 1. Investasi di Pulau Jawa (Orange) dan Pulau Sulawesi (Biru) dalam Milyar

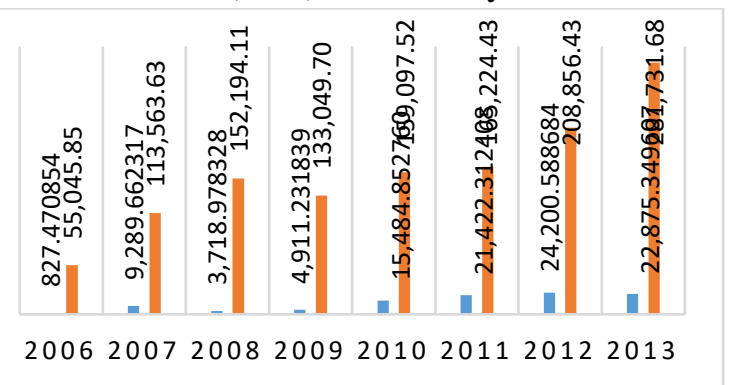

Sumber : Bps (diolah)

Grafik 2. Pertumbuhan Ekonomi Di Pulau Jawa (orange) Dan Sulawesi (biru) dalam Persen

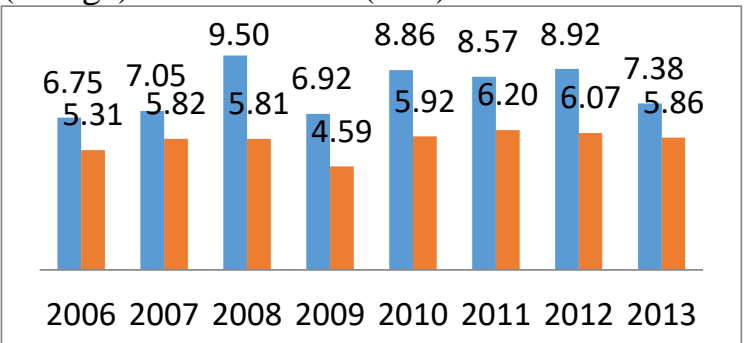

Sumber : data BPS (diolah)
Dari kedua kasus diatas jika dikaitkan dengan teori investasi, bahwa peningkatan investasi meningkatkan pertumbuhan ekonomi pula cenderung berbeda dengan fakta yang terjadi di Pulau Jawa, tetapi cenderung sama yang terjadi di Pulau Sulawesi. Seharusnya kedua pulau tersebut sama-sama mengalami pertumbuhan ekonomi yang cenderung positif. Untuk memperkuat analisa maka dibutuhkan penelitian lebih terkait relasi investasi dan pertumbuhan ekonomi seperti yang sering disebut oleh Harrod Domar.

Dari fakta yang terjadi diatas maka peneliti tertarik meneliti dengan judul: Analisis Efek Investasi Terhadap Pertumbuhan Ekonomi di Pulau Jawa dan Pulau Sulawesi tahun periode 2006-2013. Adapun tujuan penelitian adalah untuk mengetahui mengetahui efek investasi sendiri terhadap pertumbuhan ekonomi.

\section{METODE PENELITIAN}

\section{Lokasi dan Jenis Penelitian}

Penelitian ini dilaksanakan di delapan propinsi yaitu DKI Jakarta, Jawa Barat, Jawa Timur, Jawa Tengah, Sulawesi Utara, Selawesi Tengah, Sulawesi Selatan dan Sulawesi Tenggara. Jenis penelitian ini adalah penelitian kuantitaif explanatori dengan menaganalisis hubungan antar variabel. Data variabel yang digunakan adalah data sekunder dari badan pusat statistik dan sumber lainnya.

\section{Jenis Data dan Metode Analisis}

Penelitian ini menggunakan data sekunder berupa data panel yaitu gabungan time series dan cross section yang disebut data panel tahun 2006-2013 dari Badan Pusat Statistik yaitu investasi (investasi asing, investasi swasta dan belenja modal pemerintah) dan pertumbuhan ekonomi. Selanjutnya data dianalisis dengan menggunakan metode Structural Equation Model (SEM) dan diolah dengan menggunakan software ekonometrik Amos dan SPSS, dengan persamaan fungsional sebagai berikut:

$$
\mathrm{Y} 1=\mathrm{f}(\mathrm{X} 1)
$$

Dimana:

Y1 = Pertumbuhan Ekonomi

$\mathrm{X} 1$ = Tingkat Investasi

Pertumbuhan ekonomi ditentukan oleh investasi (X1). Dari persamaan (1) dapat dibentuk persamaan matematis sebagai berikut:

$$
e^{Y 1}=\alpha 0 X 1^{\alpha 1} e^{\mu 1}
$$


Untuk mengetahui berapa besar pengaruh variabel tersebut maka persamaan 1 dapat ditulis kembali dalam bentuk persamaan statistic

$$
\mathrm{Y} 1=\alpha 0+\alpha 1 \mathrm{X} 1+\mu 1
$$

Untuk memudahkan dalam pemahaman terhadap istilah dari variabel yang digunakan pada penelitian ini, maka dapat dijelaskan definisi operasional untuk tiap-tiap variabel adalah sebagai berikut:

Pertama, Pertumbuhan ekonomi adalah perubahan relatif nilai riil Produk Domestik Bruto (PDRB) di Pulau Jawa dan Sulawesi atas dasar harga konstan tahun 2000 yang dinyatakan dalam satuan persen (\%). Kedua, Investasi adalah total Investasi yang berasal dari belanja modal pemerintah, penanaman modal asing (PMA) dan penanaman modal dalam negeri (PMDN) dinyatakan dalam satuan rupiah (Rp).

\section{HASIL DAN PEMBAHASAN Hasil Penelitian}

Hasil penelitian efek investasi terhadap pertumbuhan ekonomi. Dari table 3.1. dapat dijelaskan pertama; hasil uji t signifikansi menujukkan efek investasi terhadap pertumbuhan ekonomi positif signifikan di Pulau Jawa dengan nilai signifikansi 0.000 dan positif tidak signifikan di Pulau Sulawesi dengan nilai signifikansi 0.837 . Kedua; hasil penelitian menunjukkan bahwa pengaruh investasi terhadap pertumbuhan ekonomi positif signifikan di Pulau Jawa dengan nilai estimasi 0,479 dan positif tidak signifikan di Pulau Sulawesi dengan Nilai 0.024. Berikut ini tabel hasil analisis.

Tabel 1. Hasil Analisis

\begin{tabular}{|c|c|c|c|}
\hline Wilayah & \multicolumn{3}{|c|}{ Y2 (Pertumbuhan Ekonomi) } \\
\hline (Variabel) & Koefisien & $\mathrm{t}$ (hitung) & Signifikansi $(\mathrm{P})$ \\
\hline $\begin{array}{l}\text { Pulau Jawa } \\
\text { (YI) }\end{array}$ & $\begin{array}{c}\beta 1= \\
0.479^{* * *}\end{array}$ & 5.477 & 0.000 \\
\hline $\begin{array}{c}\text { (Investasi) } \\
\text { Pulau }\end{array}$ & $\beta 1=$ & & \\
\hline $\begin{array}{c}\text { Sulawesi } \\
\text { (Y1) } \\
\text { (Investasi) }\end{array}$ & $0.024 *$ & 0.206 & 0.837 \\
\hline
\end{tabular}

Sumber : BPS (diolah)

Berdasarkan uji statistic ada dua catatan model yaitu: pertama, model yang digunakan valid. Hal ini dibuktikan dengan nilai uji $f$ signifikansi 0.000 di Pulau Jawa dan Pulau Sulawesi. Kedua, Nilai R-Square untuk Pulau
Sulawesi sebesar 65.379 persen dan Pulau Jawa sebesar 43.256 persen berarti bahwa pertumbuhan ekonomi di Pulau Sulawesi dapat dijelaskan oleh model sebesar 65.379 persen. Sedangkan Pulau Jawa hanya 43.2 persen dapat dijelaskan oleh model. Hal itu berarti bahwa 46.8 persen lainnya di pengaruhi oleh faktor lain.

\section{Pembahasan}

Hasil penelitian ini menemukan beberapa hal berdasarkan tujuan penelitian yaitu efek investasi terhadap pertumbuhan ekonomi, hasil analisis menunjukkan positif signifikan di pulau Jawa dan positif tidak signifikan di Pulau Sulawesi. Hasil penelitian ini menunjukkan bahwa pengaruh investasi terhadap pertumbuhan ekonomi berpengaruh positif signifikan di Pulau Jawa dan positif tidak signifikan di Pulau Sulawesi. Hal itu berarti bahwa setiap peningkatan investasi sebesar satu persen meningkatkan pertumbuhan ekonomi sebesar 0.479 persen di Pulau Jawa dan di Pulau Sulawesi investasi tidak berpengaruh terhadap pertumbuhan ekonomi. Hasil penelitian di Pulau Jawa sesuai dengan teori pertumbuhan ekonomi yang dikemukakan oleh Harrod \& Domar dalam Perkin (2001), Robert \& Solow dalam Arsyad (2010) dan Romer (1989) dan hasil penelitian yang dilakukan oleh Nizar (2013), Kashif et al (2013), Betterment dkk (2010), Rustiono (2008), Riyat (2012) dan Wahyuni (2014), bahwa setiap peningkatan investasi akan meningkatkan pertumbuhan ekonomi. Sedangkan hasil penelitian di Pulau Sulawesi sesuai dengan hasil penelitian Sulistiawati (2012), Abdulrahman (2013) dan Renaldi (2013), yang menemukan bahwa peningkatan investasi tidak meningkatkan pertumbuhan ekonomi. Hasil penelitiannya menemukan bahwa penyebab tidak signifikan adalah krisis ekonomi tahun 2008, bencana alam, investasi tidak merata, rendahnya pengeluaran investasi pemerintah jika dibandingkan dengan konsumsi dan terpusatnya kegiatan perekonomian diwilayah tertentu.

Perbedaan efek tersebut disebabkan oleh beberapa faktor antara lain: pertama, Sebaran investasi di Pulau Jawa lebih stabil baik dari tahun ketahun maupun dari wilayah ke wilayah lainnya. Hal yang berbeda di Pulau Sulawesi, Investasi tidak stabil, kadang sangat tinggi dan kadang pula sangat rendah pada tahun yang lain. Selain itu sebaran investasi tidak merata antara satu wilayah denan wilayah lainnya. Kedua, infrastruktur di Pulau Jawa lebih baik hal itu dilihat dari belanja modal pemerintah di Pulau Jawa jauh lebih tinggi pada struktur APBN 
dengan asumsi belanja tersebut untuk infrastruktur. Belanja modal selama 8 tahun di Pulau Jawa sebesar 66,5 triliun sementara di Pulau Sulawesi hanya 7,6 triliun padahal Pulau Sulawesi lebih luas yaitu $174.600 \mathrm{~km}$ sedangkan Pulau Jawa hanya $126.700 \mathrm{~km}$. Ketiga, Berdasarkan laporan bank Indonesia tahun 2013 tentang penggunaan investasi asing, investasi asing lebih banyak pada industry manufaktur di Pulau Jawa dengan nilai investasi \$ 8.8 milyar sector manufaktur, $\$ 2,3$ milyar untuk pertambangan dan $\$ 1.9$ milyar transportasi. Investasi di Pulau Sulawesi lebih dominan disektor Pertambangan yang meningkat terus menerus dari 2011 samapi 2013 tetapi tidak bias mendorong pertumbuhan. Keempat, Konsumsi yang terdiri dari konsumsi rumah tangga, konsumsi pemerintah dan konsumsi lembaga non profit di Pulau Jawa jauh lebih tinggi yaitu rata-rata 1.024 triliun pertahun sementara di Pulau Sulawesi hanya 67.7 triliun pertahun. Sector konsumsi menjadi penggerak utama perdagangan dan produksi. Konsumsi yang tinggi mengakibatkan investasi sector industry meningkat untuk memenuhi kebutuhan konsumsi masyarakat. Tingginya konsumsi di Pulau Jawa dipengaruhi oleh jumlah penduduk sebesar 136.610.590 jiwa sedangkan Pulau Sulawesi hanya 17.371.782 Jiwa.

Adapun implikasi hasil penelitian ini adalah berinvestasi di Pulau Jawa lebih baik sebab jika terjadi peningkatan investasi sebesar 1 $\%$ akan menyebabkan kenaikan partumbuhan ekonomi sebesar $0.479 \%$ sedangkan di Pulau Sulawesi tidak berpengaruh terhadap pertumbuhan ekonomi. Hal ini disebabkan oleh rendahnya investasi, sebaran investasi yang kurang baik, Infrastruktur kurang memadai dan objek pasar yang minim.

\section{KESIMPULAN DAN SARAN}

Adapun kesimpulan dari hasil penelitian adalah efek investasi terhadap pertumbuhan ekonomi positif signifikan di Pulau Jawa dan positif tidak signifikan di Pulau Sulawesi.

Adapun saran dari kesimpulan adalah pertama, Bagi pemerintah, yang menjadi objek penelitian yaitu DKI Jakarta, Jawa Barat, Jawa Tengah, dan Jawa Timur, Sulawesi Selatan, Sulawesi Utara, Sulawesi tengah dan Sulawesi Tenggara untuk menjaga stabilitas dan pemerataan investasi, memperbaiki infrastruktur, meningkatkan investasi disektor industry Manufaktir dan mencari objek pasar yang sesuai. Kedua, Bagi investor, berdasarkan hasil penelitian maka dapat disimpulkan bahwa jika ingin berinvestasi sebaiknya di lakukan di Pulau Jawa pada sector industri manufaktur.

\section{DAFTAR RUJUKAN}

Abdulrahman. (2013). Impact of Foreign

Direct Investment on Economic

Growth, Case Study Turki 1980-2012.

International Business Research; Vol.

5, No. 11; 2012. Canada: Canadian

Center of Science and Education.

Arsyad. (2010). Ekonomi Pembangunan:

UPP STIM YKPN

Ayoen. (2014). Pengaruh Kebijakan Tingkat

Bunga Terhadap Pertumbuhan

Ekonomi dan stabilitas Ekonomi di

Indonesia. Jawa Timur: Universitas

Pembangunan Nasional

Barro. (1990). Macroeconomics. United

State : Library Of Konggres

Betterment dkk. (2010). Analisis Faktor

Faktor Yang Mempengaruhi

Pertumbuhan Ekonomi Singapura.

Jurnal Ekonomi Pembangunan.

Sumatra Utara: Universitas Sumatra

Utara.

Bunaya, B., Musa, C. I., \& Rahmatullah, R.

(2019). Analisis Sektor-Sektor

Ekonomi Terhadap Penerimaan Daerah

Kabupaten Wajo. JEKPEND: Jurnal

Ekonomi dan Pendidikan, 2(2), 51-59.

https://doi.org/10.26858/jekpend.v2i1.9

098

Inanna, \& Rahmatullah. (2018). Wajah

Perekonomian Indonesia (1st ed.).

Makassar: Badan Penerbit Universitas

Negeri Makassar.

Kashif. et al. (2012). Spillover Effect of

Foreign Direct Investment on Economic

Growth in Pakistan et al. International

Business Research; Vol. 5, No. 11;

2012. Canada: Canadian Center of

Science and Education.

Nizar. (2013). Pengaruh Investasi dan

Tenaga Kerja Terhadap Pertumbuhan

Ekonomi Serta Hubungannya Terhadap

Tingkat Kemiskinan Diindonesia. Jurnal

Ilmu Ekonomi. PP.1-8, issn 2302-0172.

Universitas Syiah Kuala.

Perkin. et al. (2001). Economics of

Development. New York: W.W. Norton

and Company. 
Renaldi. (2013). Analisis Pengaruh

Konsumsi Pemerintah, Investasi

Pemerintah, Investasi Swasta dan

Angkatan Kerja Terhadap

Pertumbuhan ekonomi Regional (Studi

Kasus Propinsi Jawa Timur tahun

2007-2011. Jurnal ilmiah ekonomi dan

Bisnis Universitas Brawijaya. Malang:

Universitas Brawijaya.

Riyat. (2012). Faktor-Faktor yang

Mempengaruhi Pertumbuhan Ekonomi

di Enam Negara Asean. Jakarta: FE-

UI.

Ricardo. (1821). The Principle of Political

Economic and Taxation. London: G.

Wood Fall.

Romer. (1989). What The Determinant the

Rate Growth an Technological

Change?. Wassinton Dc: World Bank.

Rustiono. (2008). Analisis Pengaruh

Investasi, Tenaga Kerja, Dan

Pengeluaran Pemerintah Terhadap

Pertumbuhan Ekonomi Di Propinsi

Jawa Tengah. Semarang: Universitas

Diponegoro.

Smith. (1991). An Inquiry Intot he Nature and Causes of the Wealth Of Nation. United State: Promotheus Book.

Sulistiawati. (2012). Pengaruh Investasi Terhadap Pertumbuhan Ekonomi dan Penyerapan Tenaga Kerja serta Kesejahteraan Masyarakat di Propinsi di Indonesia.Jurnal Ekonomi Bisnis dan Kewirausahaan. Vol.3 No.129-50.

Universitas Tanjungpura Pontianak.

Sukirno. (2000). Makro Ekonomi Modern:

Perkembangan Pemikiran dari Klasik

hingga Keynesia Baru. Jakarta: Raja

Grafindo Pustaka.

Todaro. (2000). Pembangunan Ekonomi di Dunia Ketiga. Jakarta: PT. Erlangga.

Wahyuni. (2014). Pengaruh Pengeluaran

Pemerintah dan Investasi terhadap

Pertumbuhan Ekonomi dan

Kesenjangan Pendapatan

Kabupaten/Kota di Propinsi Bali. Bali:

Universitas Udayana. 